\title{
Morphological and anatomical modifications in leaf, stem and roots of four plant species under boron deficiency conditions
}

Roghieh Hajiboland, Fereshteh Farhanghi \& Mahboobeh Aliasgharpour

Plant Science Department, University of Tabriz, 51666-14779 Tabriz, Iran.

Correspondence

R. Hajiboland

E-mail: ehsan@tabrizu.ac.ir

Received: 23 may 2012

Accepted: 26 July 2012

Published on-line: 17 July 2012

\section{Resumen}

Modificaciones morfológicas y anatómicas en hoja, tallo y raíces de cuatro especies de plantas en deficiencia de boro

El boro es un componente estructural de las paredes celulares y su deficiencia causa interrupción del desarrollo. En este trabajo, se estudia la influencia del bajo suplemento de B sobre la morfología y anatomía del nabo (Brassica rapa L.), lombarda (Brassica oleracea L. var. capitata f. rubra), tabaco de pota (Nicotiana rustica L.) y apio (Apium graveolens L.). Se observaron síntomas visuales en todas las especies. El examen microscópico de secciones transversales de hojas, tallos y raíces mostró disminución del diámetro de elementos traqueales y desorganización del tejido del floema. Así mismo, se produjo hipertrofia del parénquima foliar en tabaco y adelgazamiento de paredes celulares en células del colénquima del tallo, en apio. Las alteraciones anatómicas fueron más pronunciadas en limbo, seguidas de peciolo, tallo y raíces. Estos resultados señalan importantes interrupciones en el desarrollo de los primordios foliares y los haces vasculares con carestía de B.

Palabras clave: Apio, Haces vasculares, Lombarda, Nabo, Síntomas foliares, Tabaco.

\begin{abstract}
Boron (B) is a structural component of plant cell wall and B deficiency causes disruption in development of plants. In this work, influence of low B supply on plants morphology and anatomy was studied in turnip (Brassica rapa L.), red cabbage (B. oleracea L. var. capitata f. rubra), tobacco (Nicotiana rustica L.) and celery (Apium graveolens L.). Visual B deficiency symptoms were observed in all studied species including curling of leaf margins in turnip, reduction of red coloration in red cabbage, shoot stunting in tobacco and turning dark purple colors in celery. Microscopic examination of cross-sections revealed that diameter of tracheary elements decreased and the phloem tissue became disorganized. Hypertrophy of leaf parenchyma cells in tobacco and increased thickening of collenchyma cell walls in the stem of celery were also observed. Anatomical alterations due to $B$ deficiency were more pronouncedly observed in the leaf blades followed by the petiole, stem and roots. Our results indicated that remarkable disruptions occur in development of leaf primordia and vascular bundles upon B starvation.
\end{abstract}

Key words: Celery, Leaf symptoms, Red cabbage, Tobacco, Turnip, Vascular bundles. 


\section{Introduction}

Boron (B) deficiency is the most widespread micronutrient deficiency affecting the productivity of many important crops (Marschner 1995, Blevins \& Lukaszewski, 1998, Mengel \& Kirkby 2005). Boron deficiency causes impairment of growth, death of growing meristems and inhibition of vascular bundles development (Brown et al. 2002).

The fact that severe B deficiency symptom occurs in the growing leaves but not in the fully mature leaves suggests that the primary function of B in plant is likely restricted to its involvement in plant development (Brown and Hu 1997). An important characteristic of growing tissue is cell division and elongation. In this regard B may be required in some process critical to the synthesis of cellular materials or as a structural component of the cell during cell enlargement and division.

The possibility that B plays a structural role in the growing tissues in the plant has received much experimental support. A role in the cell wall cross links (Loomis \& Durst, 1992) has been suggested and B-pectin complex has been isolated and characterized (Matoh \& Kobayashi 2002). A fundamental role in the physical structure of expanding cell walls was demonstrated for different plant species (Hu \& Brown 1994). It was proposed that dimeric rhamnogalacturonan-II-borate is an essential component of the covalently cross-linked pectic matrix of dicots and non-graminaceous monocot walls and a cross-linked pectic matrix may participate in regulating the rate of cell growth (O’Neil et al. 1996). A significant reduction of the cell wall elasticity modulus in roots immediately upon transfer to $\mathrm{B}$ free nutrient solution suggests a role of B in crosslinking cell wall macromolecules (Findeklee \& Goldbach 1996). The proposed role of $B$ in the structure of primary cell walls can explain almost all the reported effects of B deficiency (Matoh \& Kobayashi 2002).

In addition of the role in cell wall structure, it has been proposed that B deficiency could affect metabolism of phenolics (Cakmak \& Römheld 1997), lignin biosynthesis and xylem formation (Marschner 1995) and thus may inhibit vascular bundles development (Brown et al. 2002). Accordingly, B deficiency is expected to cause dramatic structural and anatomical changes. Researches on the effects of B starvation are mostly focused on physiological and biochemical responses of plants and works on B-deficiency-induced disruption of development and organization of tissues are rare.

Apart from some works published more than 40 years ago, a few works were devoted to the anatomy of B-deficient plants. In faba bean, xylem malformation occurred in plants exposed to B deficiency for more than $24 \mathrm{~h}$ (Robertson \& Loughman 1974). Boron deficiency in cotton led to necrosis of the xylem tissue and the xylem vessels wall was thickened and vessels were observed in lower number, with an irregular perimeter (Sanfuentes 1966). In another work on cotton, the number of vascular bundles of the petiole was decreased, phloem elements did not differentiate and vascular tissues were disorganized (de Oliveira 2006). When B was replaced in the nutrient solution after a temporary deficiency, growth recovery of the cotton plants was not complete (Rosolem \& Costa 2000), leading to the conclusion that a temporary B deficiency causes permanent damage to the plant. Hypertrophy and size modification of the cortex cells and poor differentiation of the vascular tissues were reported in B-deficient common bean plants (Moraes- Dallaqua 1992). In B-deficient coffee plants, vascular tissues were disorganized and xylem walls were thinner. Boron-deficient leaves had fewer and deformed stomata (Rosolem \& Leite 2007).

Turnip, red cabbage, tobacco and celery are important horticultural and agricultural species with different susceptibility to B deficiency. Species from Brassica and Apium were considered as the most responsive species to the application of $\mathrm{B}$ fertilizers under field conditions and symptom of B deficiency was also reported for tobacco (Shorrocks 1997). In addition of physiological and biochemical responses of plants to B deficiency, it is also necessary to study developmental and structural modifications in plants that may influence in turn some important physiological functions. Our previous work showed that B-deficient turnip plants were more susceptible to drought stress likely because of an impaired xylem vessel differentiation (Hajiboland \& Farhanghi 2011). This study was aimed to investigate structural and anatomical changes caused by B deprivation in leaf, stem and roots of four different species. An especial emphasize was made on turnip plants because of its greater susceptibi- 
lity to B deficiency conditions.

\section{Materials and methods}

\section{Plant material and cultivation}

Seeds of turnip (Brassica rapa L.), red cabbage (Brassica oleracea L. var. capitata f. rubra), tobacco (Nicotiana rustica L.) and celery (Apium graveolens L.) plants purchased from commercial sources, were surface-sterilized using sodium-hypochlorite at $5 \%$ and germinated in the dark on filter paper soaked with saturated $\mathrm{CaSO}_{4}$ solution. Seven-day-old young seedlings were pre-cultured for two weeks in 50\% nutrient solution (Hoagland \& Arnon 1950). Thereafter, plants were transferred to the treatment solutions with full strength nutrient solution containing either low $(<0.25 \mu \mathrm{M}$ as contamination of nutrient solution, $-\mathrm{B})$ or adequate $(25 \mu \mathrm{M},+\mathrm{B})$ supply of $\mathrm{B}$. Nutrient solutions were changed regularly and $\mathrm{pH}$ was adjusted each day to 6.5. Plants were grown under controlled environmental conditions with a temperature regime of $25^{\circ} / 18^{\circ} \mathrm{C}$ day/night, $14 / 10 \mathrm{~h}$ light/dark period, a relative humidity of $70 / 80 \%$ and at a photon flux density of about 400 $\mu \mathrm{mol} \mathrm{m} \mathrm{s}^{-1}$.

\section{Plant harvest and B analysis}

Four weeks after starting treatments, plants were harvested. Plants were divided into leaves and root and dried at $70^{\circ} \mathrm{C}$ for 2 days to determine dry weight. Another group of plants were used for morphological and anatomical studies.

\section{Morphologic and structural studies}

Preliminary observations were made for morphological characterization of leaf symptoms. After observation with naked eyes or binuclear, photographs were made if necessary. Visual leaf symptoms were detected firstly in the young leaves, accordingly, the third youngest leaf that does not expand further in both B-sufficient and B-deficient plants were selected for anatomical studies. Selected leaves did not show any chlorotic or necrotic lesions at this stage. Samples of $5 \mathrm{~mm}$ around leaf midribs, the middle region of petiole (turnip and red cabbage at rosette stage) or stem (tobacco and celery) and the $2-5 \mathrm{~mm}$ of basal part of root (turnip) were excised and immediately fixed in formalin-acetic acid-alcohol (FAA) (Jensen 1962) and stored at $4{ }^{\circ} \mathrm{C}$ until sectioning. After preparation of free hand sections, samples were washed with distilled water and placed in $5 \%$ sodium hypochlorite solution for $20 \mathrm{~min}$ for clearing and rinsed with distilled water. Following washing in $10 \%$ acetic acid for $2 \mathrm{~min}$, sections were then stained with methyl green and carmine for lignin and cellulose respectively. Sections were embedded and mounted in glycerol. Thin cut sections were observed under a microscope fitted with digital camera (Motic images plus 2.0) and attached with a computer.

\section{Results}

\section{Effect of B deficiency on plants growth}

Dry matter production of shoot and root was negatively influenced by low B supply in all four studied species (Table 1). Reduction of dry weight of shoot was $66 \%, 65 \%, 64 \%$ and $70 \%$ in turnip, red cabbage, tobacco and celery respectively. The corresponding values for root dry weight was $80 \%, 57 \%, 76 \%$ and $82 \%$. Accordingly, the extent of reductions in shoot dry weight was similar among studied species while regarding root dry weight, red cabbage was much less affected than other three species.

\begin{tabular}{lcccc} 
& & Shoot DW & Root DW & Shoot/Root \\
\hline \multirow{2}{*}{ Turnip } & $+\mathrm{B}$ & $543 \pm 156^{\mathrm{a}}$ & $62.4 \pm 13.6^{\mathrm{a}}$ & 8.70 \\
& $-\mathrm{B}$ & $242 \pm 110^{\mathrm{b}}$ & $17.2 \pm 7.9^{\mathrm{b}}$ & 14.07 \\
\hline \multirow{2}{*}{ Red } & $+\mathrm{B}$ & $677 \pm 105^{\mathrm{a}}$ & $55.8 \pm 9.7^{\mathrm{a}}$ & 12.13 \\
cabbage & $-\mathrm{B}$ & $326 \pm 50^{\mathrm{b}}$ & $38.3 \pm 6.7^{\mathrm{b}}$ & 8.51 \\
\hline \multirow{2}{*}{ Tobacco } & $+\mathrm{B}$ & $878 \pm 145^{\mathrm{a}}$ & $175 \pm 57^{\mathrm{a}}$ & 5.02 \\
& $-\mathrm{B}$ & $304 \pm 116^{\mathrm{b}}$ & $52 \pm 20^{\mathrm{b}}$ & 5.84 \\
\hline \multirow{2}{*}{ Celery } & $+\mathrm{B}$ & $1163 \pm 252^{\mathrm{a}}$ & $497 \pm 94^{\mathrm{a}}$ & 2.34 \\
& $-\mathrm{B}$ & $462 \pm 117^{\mathrm{b}}$ & $64 \pm 28^{\mathrm{b}}$ & 7.22 \\
\hline
\end{tabular}

Tabla 1. Peso seco de brote y raíz $\left(\mathrm{mg}\right.$ planta $\left.^{-1}\right)$ y proporción brote/raíz de cuatro especies de plantas cultivadas en condiciones adecuadas $(+B)$ o deficientes (-B) de boro durante 4 semanas. En cada columna, letras diferentes indican diferencias significativas (Tukey, $\mathrm{P}<0.05$ )

Table 1. Shoot and root dry weight $\left(\mathrm{mg}\right.$ plant $\left.^{-1}\right)$ and the ratio of shoot/ root (on dry weight basis) in four plant species grown under adequate $(+\mathrm{B})$ or low $(-\mathrm{B}) \mathrm{B}$ supply in the nutrient solution for four weeks. Difference between data in each column within each plant species followed by different letters were statistically significant (Tukey, $\mathrm{P}<0.05$ ). 

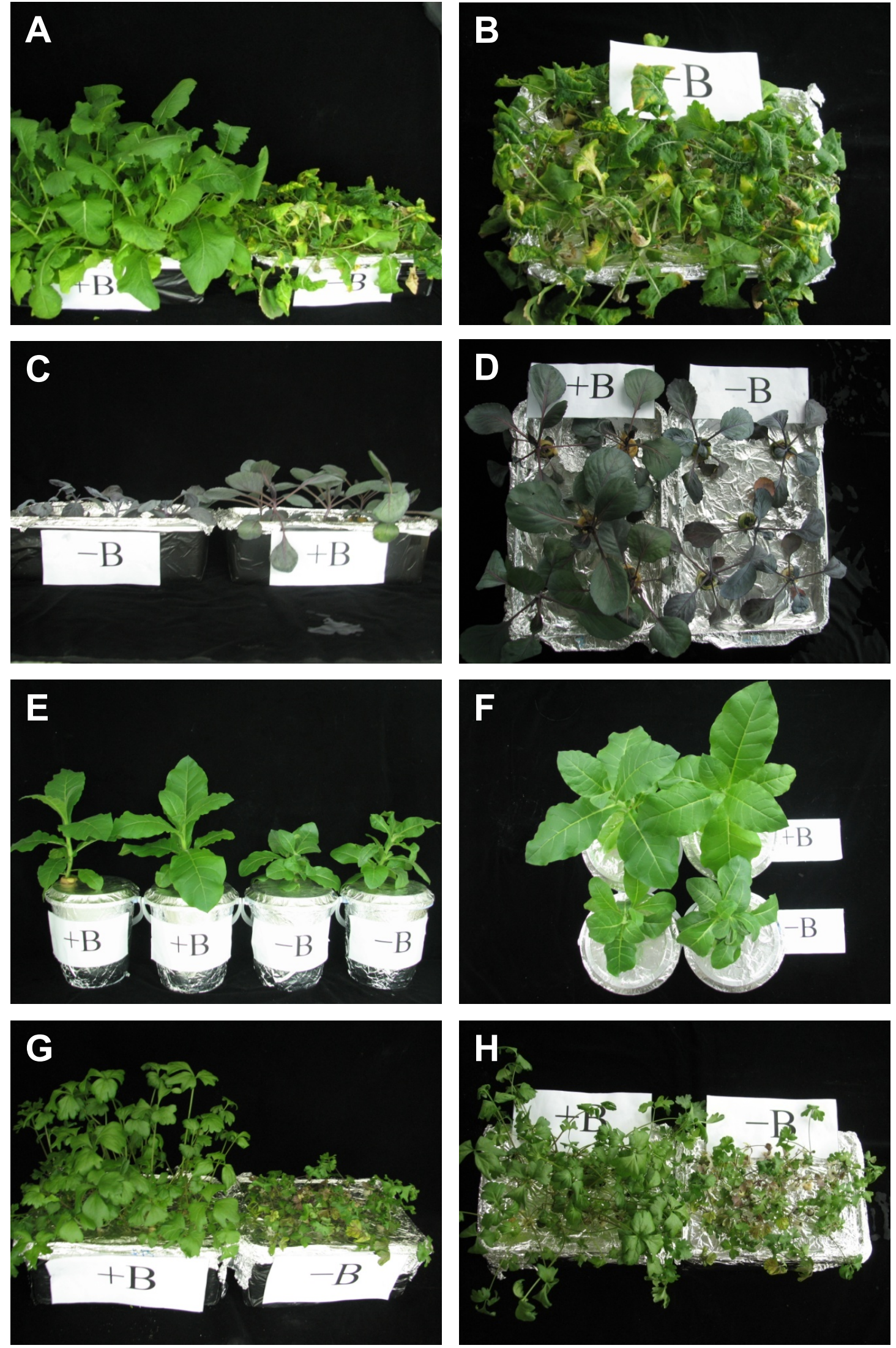

Figura 1. Crecimiento de plantas de nabo (A, B), lombarda (C, D), tabaco (E, F) y apio $(\mathrm{G}, \mathrm{H})$ cultivadas hidropónicamnete en concentraciones de boro adecuadas $(+\mathrm{B}) \mathrm{o}$ insuficientes $(-\mathrm{B})$, durante cuatro semanas.

Figure 1. Growth of turnip (A, B), red cabbage $(C, D)$, tobacco $(E, F)$ and celery $(G, H)$ plants cultivated hydroponically under adequate $(+B)$ or low (-B) supply of B for four weeks. 


\section{Changes in plant morphology under B deficiency and visual symptoms of B deficiency}

Visual B deficiency symptoms were observed firstly in roots of B-deficient plants 2-5 days after imposition of B deficiency without considerable difference among examined species. The main axis of roots was reduced but number of lateral roots per length of the primary root was increased and roots turned light brown color.

The symptoms progressed to shoots 7-10 days after starting low B treatment and typical symptoms of B deficiency were appeared firstly in the young leaves of all species. Leaves of B-deficient plants presented reduced surface area and increased leaf lamina thickness combined with thickening and shortening of petioles and stems.

In turnip plants young leaves showed dark green color and an uneven curling of leaf margins towards the abaxial surface. Young leaves that were being emerged during the late period of experiment showed symptoms more pronouncedly and ceased further growing, became chlorotic, necrotic and fall off (Fig. 1 A, B).

Dramatic reduction in leaf size was observed in red cabbage plants under B deficiency conditions. In this species leaf symptoms were mainly restricted to discoloration of leaves as considerable reduction of red coloration and chlorosis at later growth stages (Fig. 1 C, D).

In tobacco plants, minor leaf curling was detected but leaves were significantly smaller and narrower compared with control plants. Chlorosis or necrosis was not observed until harvest in this species, however, reduction of apical dominance and activation of lateral buds was detected in Bdeficient plants associated with significantly shorter internodes (Fig. 1 E, F).

In celery, the most important leaf symptom was discoloration of leaves. They turned red and dark purple colors, at the later stages of growth they became chlorotic and necrotic (Fig. $1 \mathrm{G}, \mathrm{H}$ ).

\section{Effect of B deficiency on anatomy of leaf blade}

Light microscopy of transverse sections of young leaves showed considerable anatomical alterations due to B deficiency.

Turnip: The leaf vascular bundles were increased in the number and size. However, diameter of xylem vessel elements decreased in spite of increase in the number. In contrast to xylem, the phloem tissue was expanded but became significantly disorganized and collenchyma was reduced (Fig. 2).

Red cabbage: Alteration in the leaf anatomy of red cabbage plant due to B deficiency was similar with that observed in turnip. However, the number of vascular bundles rather decreased because of joining dorsal and lateral vascular bundles. Increase in the leaf thickness was more obvious than turnip plants that was due to hypertrophy of leaf parenchyma cells and expansion of vascular bundle (Fig. 3).

Tobacco: The size of single vascular bundle of leaf was not influenced by B deficiency and disorganization of phloem was much less expressed compared with other two species. Hypertrophy of leaf parenchyma cells, however, was more pronounced in comparison with other two species (Fig. 4).

Celery: Leaf thickness was increased significantly and hypertrophy of the cells around midrib was obvious. The palisade parenchyma was increased in length particularly at adaxial surface. The size of single leaf vascular bundle was not affected significantly by B deficiency but xylem vessel elements decreased significantly in diameter. In contrast to turnip and red cabbage, only minor phloem disorganization was observed (Fig. 5).

\section{Effect of B deficiency on anatomy of petioles and stem}

Because turnip and red cabbage plants were at rosette growth stage during the experiment, leaf petioles instead of stem were subjected to sectioning and staining in these species. Similar alterations in the anatomy including phloem disorganization (in turnip, Fig. 6 B, D) and expansion of vascular bundles (red cabbage, Fig. 7 A, C) were observed in the petiole of these species. However, all these changes were much less expressed compared with the leaf blades. Cell wall thickness of xylem parenchyma cells located within and around dorsal bundles in the red cabbage petiole was considerably higher than control plants (Fig. 7 B, D). Stem of tobacco (Fig. 8) and celery (Fig. 9) showed also much less modifications in the anatomy due to $\mathrm{B}$ deficiency compared to the leaves. 
The epidermis of celery stem consisted of some layers of rectangular cells. In the edges of the stem and directly beneath the epidermis collenchyma tissue concentrated under the corners and contained several thick-walled cell layers (strings). Cell wall thickening of collenchyma cells was considerably higher in the stem of B-de-
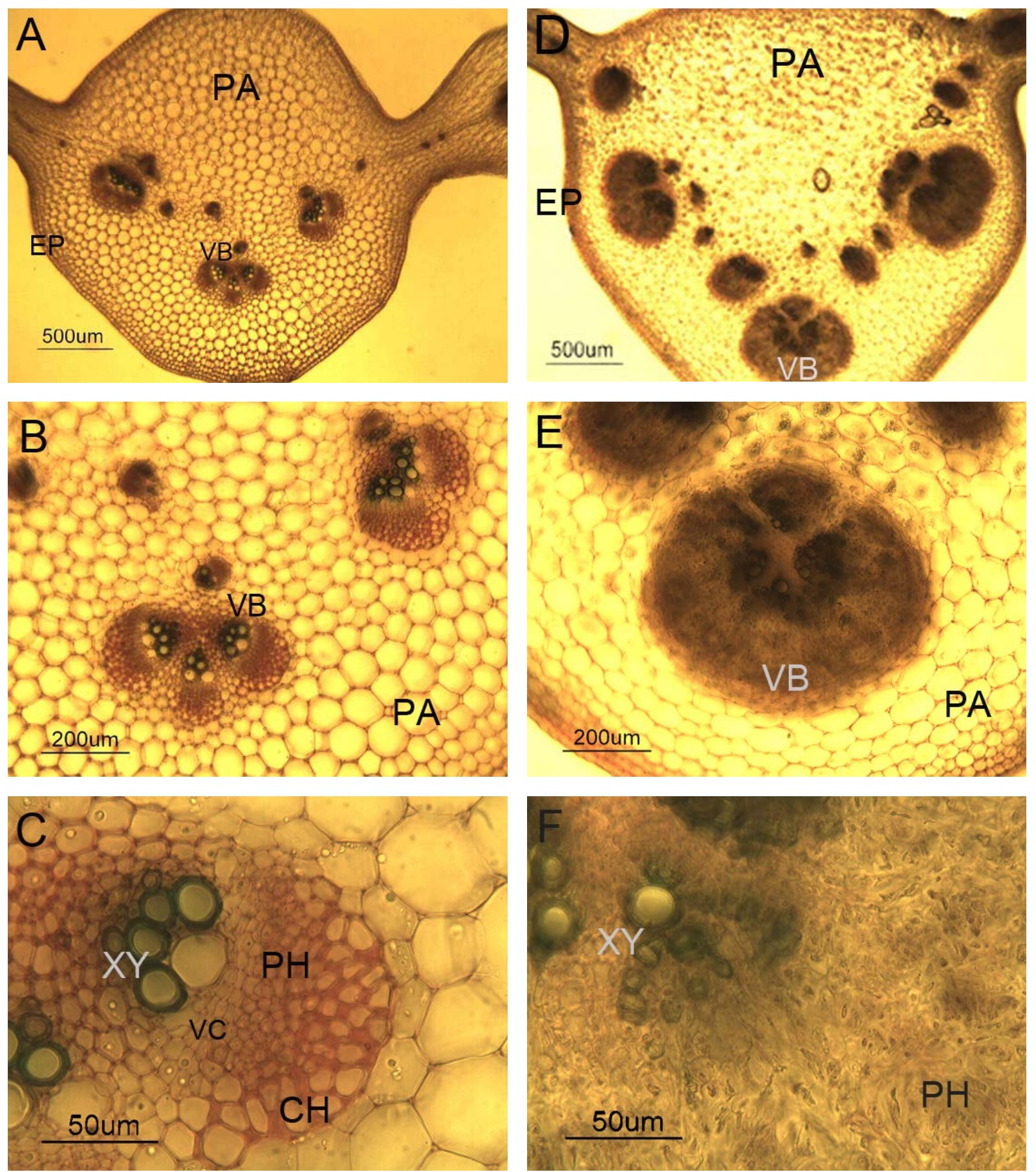

Figura 2. Sección transversal de hojas de nabo cultivado bajo condiciones adecuadas (A, B, C) y deficitarias (D, E, F) de boro. EP: epidermis; PA: parénquima; VB: haces vasculares; XY: xilema; PH: floema; $\mathbf{C H}$ : colénquima; VC: cambium vascular.

Figure 2. Cross sections of turnip leaves grown under adequate (A, B, C) or low (D, E, F) B supply. EP: epidermis; PA: parenchyma; VB: vascular bundles; $\mathbf{X Y}$ : xylem; PH: phloem; $\mathbf{C H}$ : collenchyma; VC: vascular cambium. 


\section{Effect of B deficiency on anatomy of roots}

Root anatomy was studied only in turnip plants. Boron-deficiency-induced anatomical changes, similar with that in the petioles and stems, were less expressed compared with the leaf blades. Nevertheless, reduction in the size of tracheary elements and change in their organization as aggregation of xylem vessel elements was obvious (Fig. 10 A, D). But in contrast to aerial parts, phloem tissue was significantly reduced in roots of B-deficient plants and was also significantly disorganized (Fig. 10 B, E). Swelling and forma-
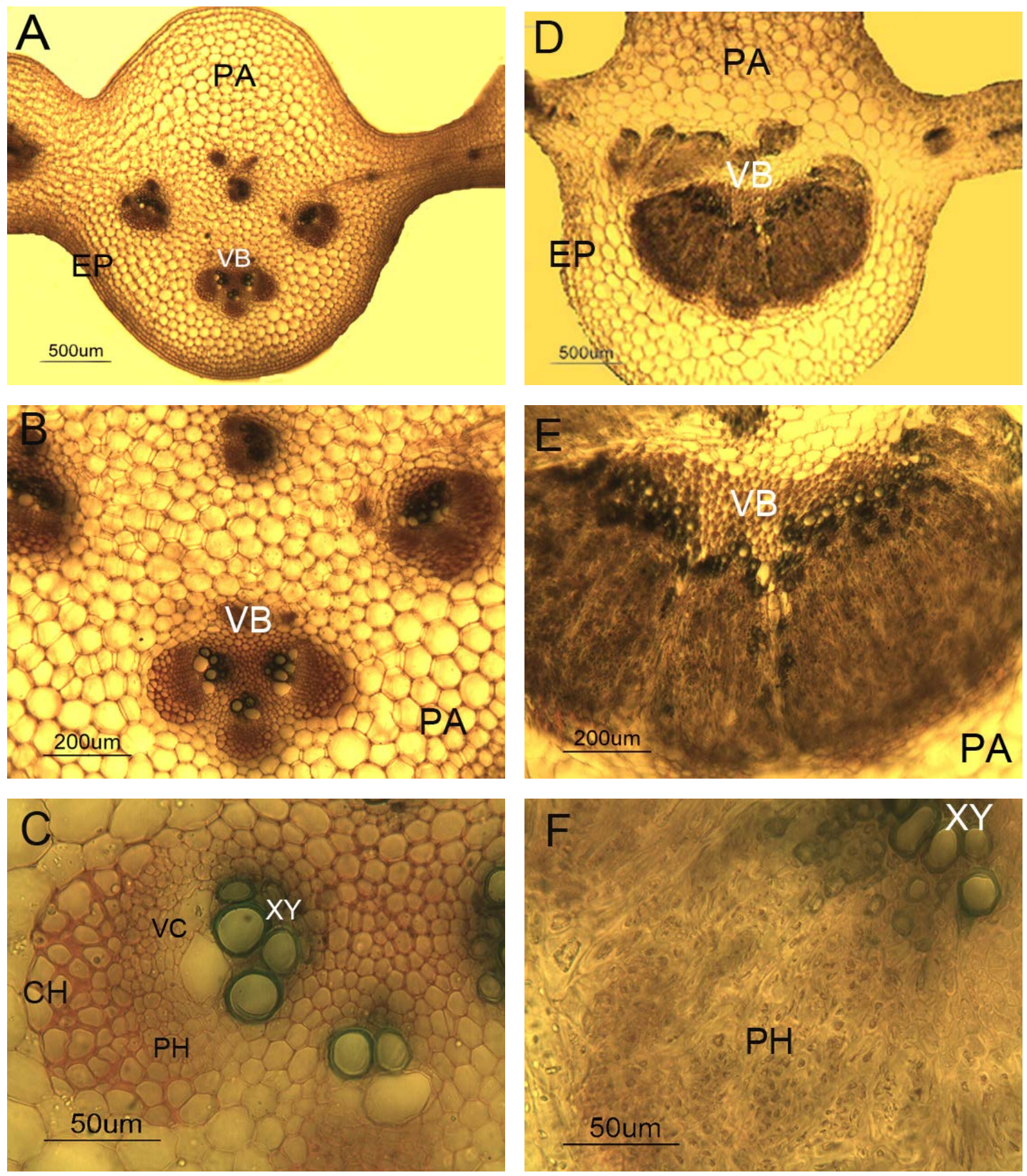

Figura 3. Sección transversal de hojas de lombarda cultivada bajo condiciones adecuadas (A, B, C) y deficitarias (D, E, F) de boro. EP: epidermis; PA: parénquima; VB: haces vasculares; XY: xilema; PH: floema; $\mathbf{C H}$ : colénquima; VC: cambium vascular.

Figure 3. Cross sections of red cabbage leaves grown under adequate (A, B, C) or low (D, E, F) B supply. EP: epidermis; PA: parenchyma; VB: vascular bundles; XY: xylem; PH: phloem; CH: collenchyma; VC: vascular cambium. 
tion of storage root was considerably lower in Bdeficient plants and it was much smaller in diameter than that in control plants (data not shown). The area of xylem tissue appeared to be expanded (data not shown) but that of phloem was rather slightly decreased (Fig. 10 C, F).

\section{Discussion}

Plants growth was strongly inhibited under B deficiency conditions. Growth impairment was higher for root compared with that for shoot leading to an increase in the shoot/root dry weight ratio in studied species except for red cabbage. Higher susceptibility of root growth as compared with shoot growth has also been reported by other authors (Camacho-Cristóbal \& González-Fontes 1999). Inhibition of root elongation is the most rapid response to B deficiency that occurs as soon as three hours after the B supply is interrupted (Marschner
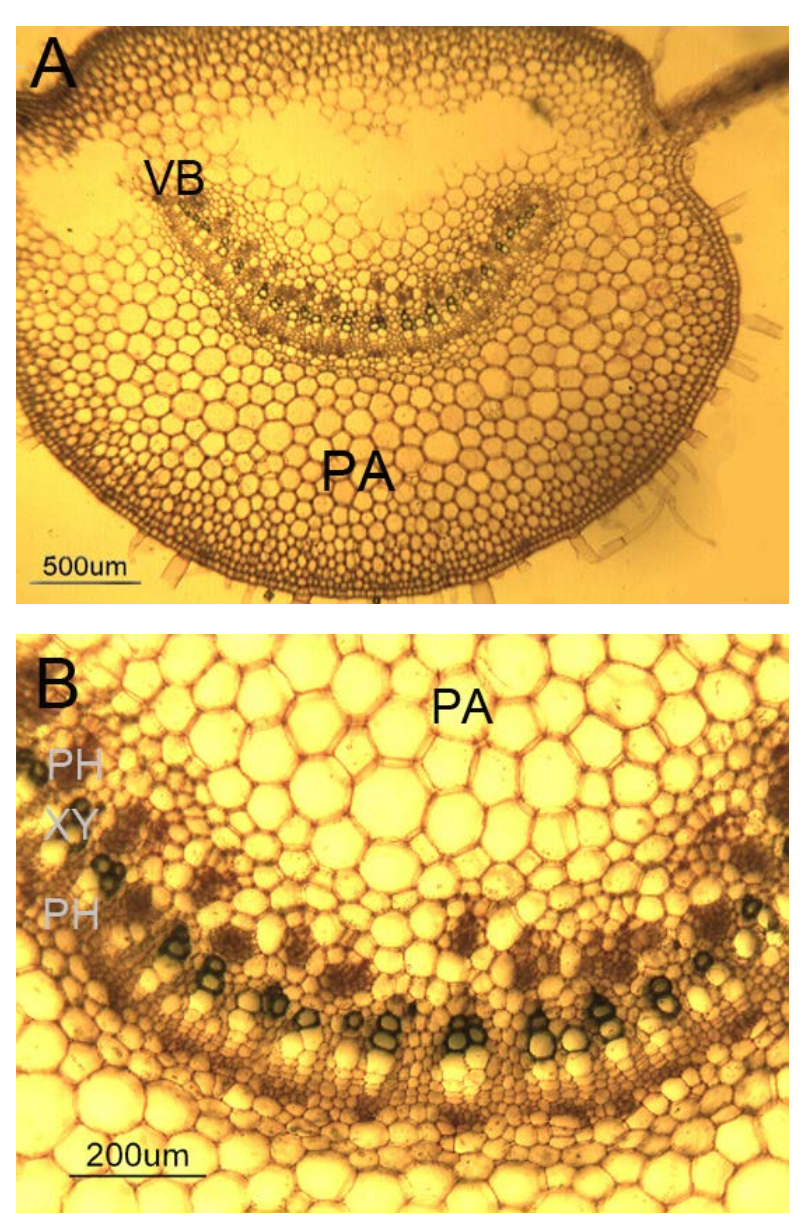

1995). Root elongation is the result of various processes including cell division and cell elongation, the latter is associated with loosening and reforming of cross-links in the cell wall (Wolf et al. 2012). Considering B as a structural component required for the stability of rhamnogalacturonan-II cross-links in the pectin matrix of the cell wall (O'Neill et al. 2001, 2004), cessation of cell elongation is expected under B deficiency conditions. Boron deficiency alters the physical properties (extensibility and plasticity) of the cell wall and, therefore, impairs cellular elongation (Broadley et al. 2012). The expression of several genes coding for cell wall-modifying enzymes is downregulated under B deficiency, which could alter the cell wall loosening required for cell elongation (CamachoCristóbal et al. 2008). It has also been proposed that $\mathrm{B}$ deficiency decreases cell division in root meristematic regions (Dell \& Huang 1997), although this effect has not been observed by other
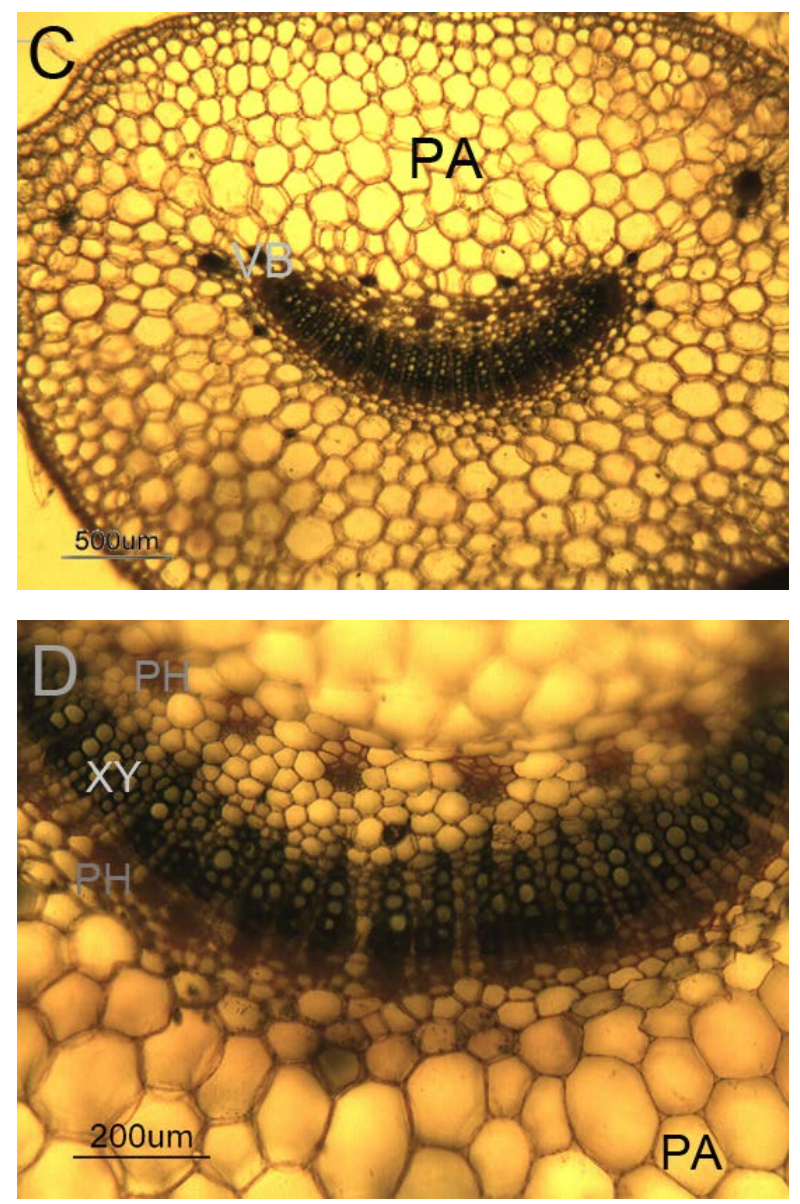

Figura 4. Sección transversal de hojas de tabaco de pota cultivado bajo condiciones adecuadas (A, B) y deficitarias (C, D) de boro. EP: epidermis; PA: parénquima; VB: haces vasculares; XY: xilema; PH: floema; $\mathbf{C H}$ : colénquima; VC: cambium vascular.

Figure 4. Cross sections of tobacco leaves grown under adequate (A, B) or low (C, D) B supply. EP: epidermis; PA: parenchyma; VB: vascular bundles; XY: xylem; PH: phloem; $\mathbf{C H}$ : collenchyma; VC: vascular cambium. 
authors (Martín-Rejano et al. 2011) and is probably a secondary effect of this mineral deficiency (Dell \& Huang 1997). It has been proposed that, changes in the cell wall structure and functions are the primary effects of B deficiency leading to a cascade of secondary effects in growth and metabolism of plants (Broadley et al. 2012).

In the roots of B-deficient plants, we observed more lateral root initiation and higher-order lateral root branching. In addition, apical dominance was reduced and lateral buds were activated in the shoot of tobacco plants grown under B deficiency conditions (data not shown). Both of these symptoms resulted likely from impairment of the activity of root and shoot apical meristems. Boron is essential for actively growing regions of plants such as root tips (Martín-Rejano et al. 2011) and is important for development of leaf primordia in buds (Marschner 1995). Rosetting and stunting of plants observed in tobacco plants in this work has
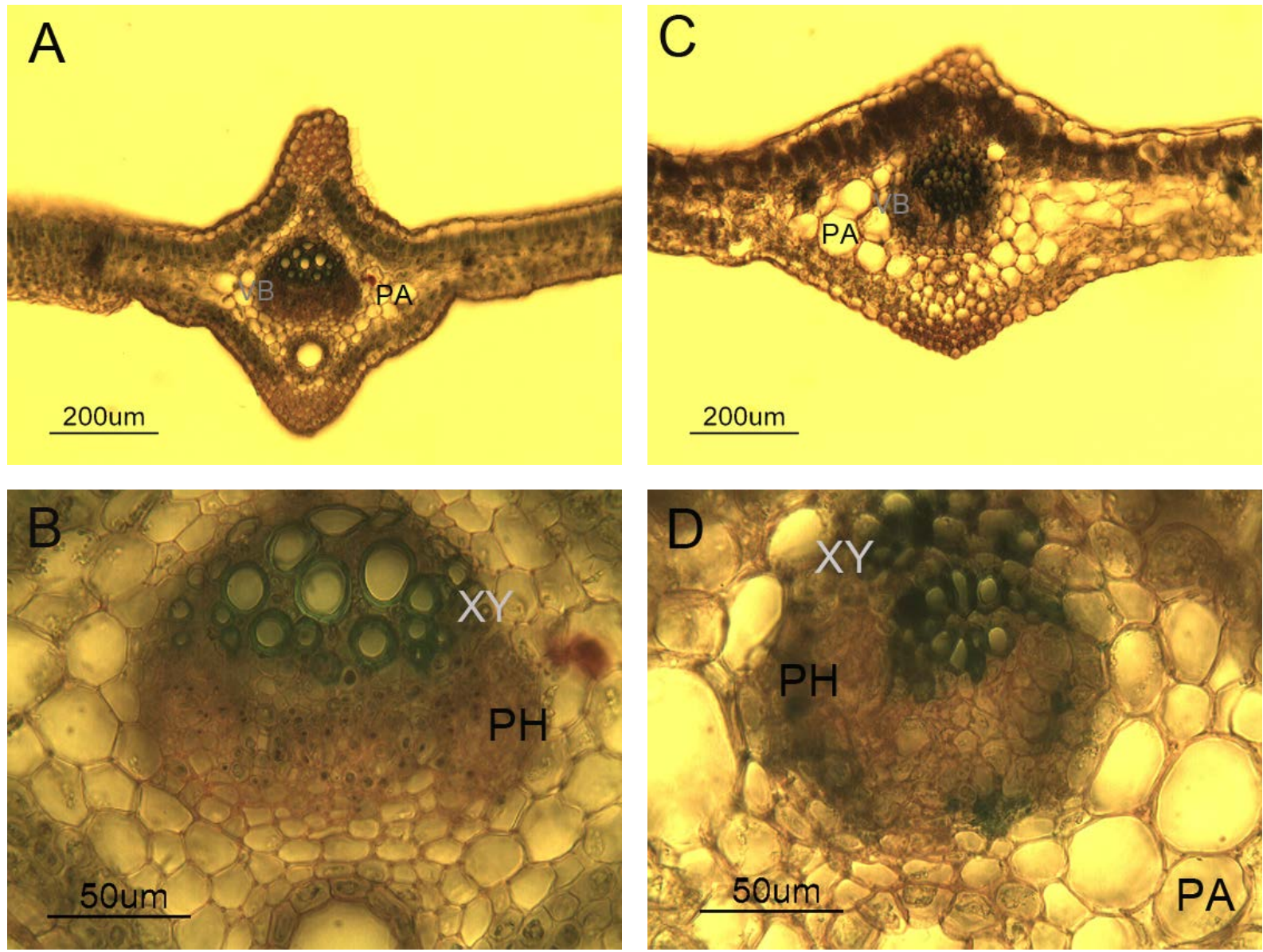

Figura 5. Sección transversal de hojas de apio cultivado bajo condiciones adecuadas (A, B) y deficitarias (C, D) de boro. EP: epidermis; PA: parénquima; VB: haces vasculares; XY: xilema; PH: floema; CH: colénquima; VC: cambium vascular.

Figure 5. Cross sections of celery leaves grown under adequate (A, B) or low (C, D) B supply. EP: epidermis; PA: parenchyma; VB: vascular bundles; XY: xylem; PH: phloem; CH: collenchyma; VC: vascular cambium. 
1999, Hajiboland \& Farhanghi 2010) and may be the result of an increased membrane damage and disruption of chloroplast structure due to B deficiency (Cakmak \& Römheld 1997). However, strong inhibition of leaf expansion may cause accumulation of chlorophyll in leaf blades as was observed in turnip plants in this work. Red coloration of celery is likely the result of reduction of chlorophyll under B deficiency conditions. Boron deficiency induces change in the phenolics metabolism (Cakmak \& Römheld 1997) including anthocyanins, thus changes in the leaf anthocyanin content is also expected. Decline and increase in the anthocyanin content of leaves has been reported depending on the age of leaves and lighting conditions (Hajiboland et al. 2011).

Considerable wall thickening was observed in xylem parenchyma cells and collenchyma tissue in the petiole of red cabbage (Fig. 7 D) and stem of celery (Fig. 9 D) respectively. In contrast to our results, reduction of cell wall thickness was observed in roots of tomato (Kouchi \& Kumazawa 1976) and leaves of cotton (de Oliveira et al. 2006). Such discrepancy could be explained likely as species differences. In our work, four examined species did also considerably differ in the anatomical modifications induced by $\mathrm{B}$ deficiency.

Enlargement of vascular bundles under B deficiency conditions was not associated with development of wider tracheary elements. In contrast, tracheary elements diameter of B-deficient plants seemed to be rather narrow compared with control samples as could typically be observed in the leaf vascular bundles of turnip (Fig. 2 C, F) and celery (Fig. 5 B, D). Xylem malformation in faba bean (Robertson \& Loughman 1974), necrosis of xylem tissue and thickening of xylem vessels wall (Sanfuentes 1966) and lack of differentiation of xylem vessels (de Oliveira et al. 2006) have been reported in cotton. In our work, lignification per se,
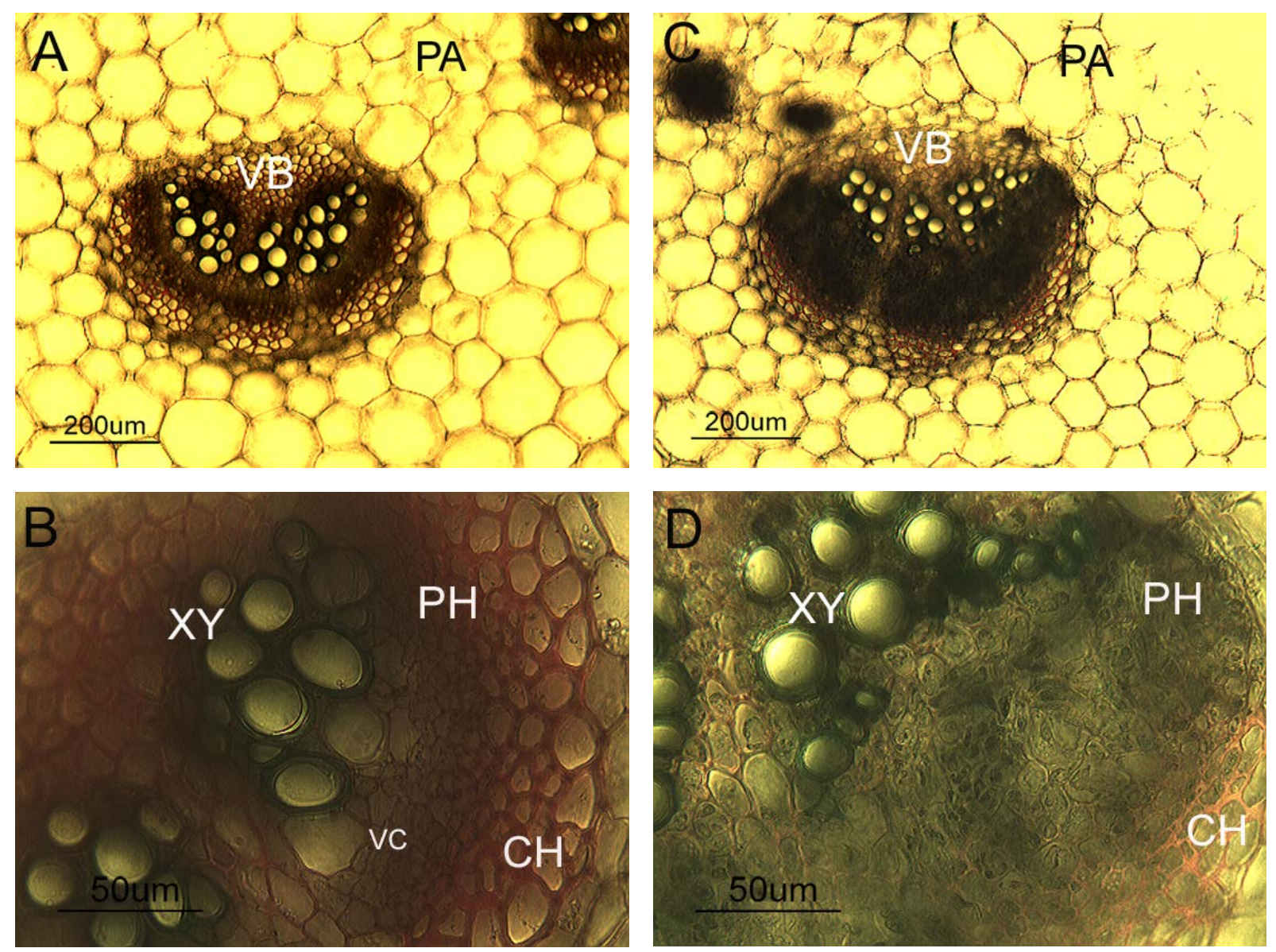

Figura 6. Sección transversal de peciolos de nabo cultivado bajo condiciones adecuadas (A, B) y deficitarias (C, D) de boro. EP: epidermis; PA: parénquima; VB: haces vasculares; XY: xilema; PH: floema; CH: colénquima; VC: cambium vascular.

Figure 6. Cross sections of turnip petioles grown under adequate (A, B) or low (C, D) B supply. EP: epidermis; PA: parenchyma; VB: vascular bundles; XY: xylem; PH: phloem; CH: collenchyma; VC: vascular cambium. 
i.e. wall thickening of tracheary elements, was not influenced by B deficiency but differentiation of xylem tissue was significantly disrupted under these conditions.

Many of the morphological and anatomical changes observed in B-deficient plants in this work could be likely related to an alteration in the balance of plant hormones particularly auxin and ethylene. The phytohormones auxin, cytokinin, ethylene, and gibberellins are the major regulators of cell specification, proliferation, and expansion in the roots, and extensive crosstalk between them can ensure rapid responses to external and internal cues. Auxin controls not only the initiation and proliferation of cells in the proximal meristem but also cell elongation and the differentiation of cells leaving the meristem (Stahl \& Simon 2010). Modifications in the patterning of vascular bundles including disruption of xylem differentiation and disorganization of phloem tissue together with short internodes and cessation of apical bud development and reduced apical dominance observed in this work all are common responses of plants to the reduction in auxin levels (Davies 1987, Marschner 1995). Changes in the auxin metabolism and in the pattern of auxin polar transport under B deficiency conditions had been previously suggested (Cakmak \& Römheld 1997) and were supported in recent years by molecular evidences (Martín-Rejano et al. 2011). The activity of auxin responsive genes in the transition and elongation zones increased under low B supply, suggesting that the pattern of auxin distribution in the root tip is affected by low B treatment (Martín-Rejano et al. 2011). Hence, the inhibition of root elongation under low B treatment could be caused, at least partly, by changes in auxin distribution in the tip (Martín-Rejano et al. 2011). Involvement of auxin in the responses of the root system architecture has been also demonstrated for phosphorus defi-
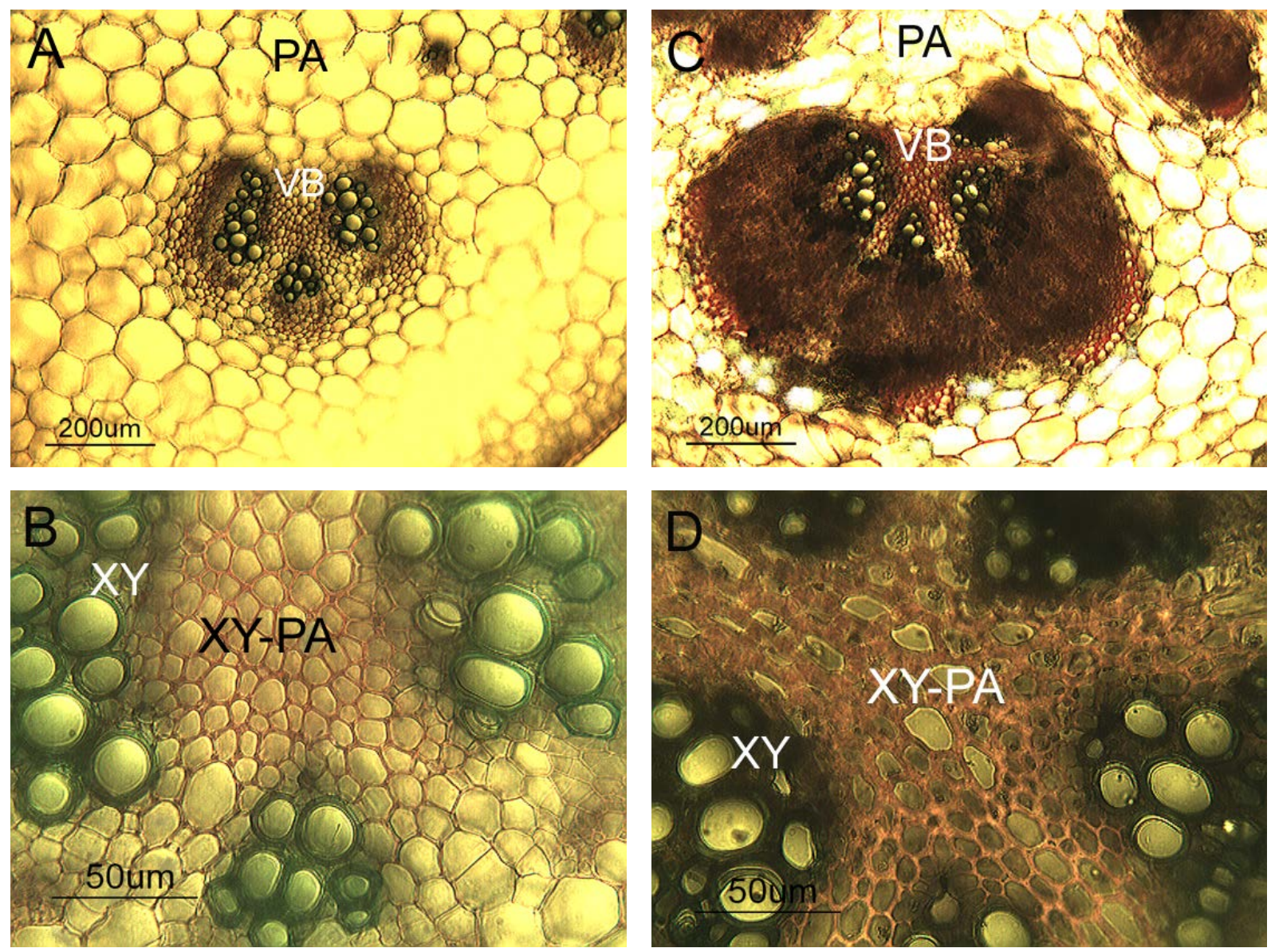

Figura 7. Sección transversal de peciolos de lombarda cultivada bajo condiciones adecuadas (A, B) y deficitarias (C, D) de boro. EP: epidermis; PA: parénquima; VB: haces vasculares; XY: xilema; PH: floema; CH: colénquima; VC: cambium vascular.

Figure 7. Cross sections of red cabbage grown under adequate (A, B) or low (C, D) B supply. EP: epidermis; PA: parenchyma; VB: vascular bundles; XY: xylem; PH: phloem; $\mathbf{C H}$ : collenchyma; VC: vascular cambium. 
ciency conditions (Pérez-Torres et al. 2008). Differentiation of vascular cambium cells into xylem or phloem precursors depends on their positions and auxin acts as a patterning agent for differentiation and spacing of vascular bundles (Ye 2002). The observed reduction in tracheary elements diameter could be also attributed to a decline in auxin level. It was observed that higher auxin levels cause differentiation of both xylem and phloem while no xylem is differentiated in the absence of enough auxin (Davies 1987). Formation of narrower tracheary elements is likely because of decline in expansion of precursor cells via the mechanisms discussed above.

On the other hand, hypertrophy of the cells, thickening of leaf lamina, petioles and stems and higher root branching are the symptoms for some stresses triggering excess ethylene production (Davies 1987). Thus, it could be also suggested that B-deficient plants produce higher amounts of ethylene likely as a common response to this nutritional stress. Molecular evidence is lacking on the function of apical shoot meristem and development of leaves under the effect of low B supply. For roots, however, recent molecular evidences showed that activity of ethylene-responsive genes was increased in the elongation and maturation zones of the roots under low B treatment which would suggest an ethylene accumulation and induction of local ethylene responses in these zones (Martín-Rejano et al. 2011). Ethylene affects root growth by inhibiting the rapid expansion of cells leaving the root meristem (Le et al. 2001). It has been also reported that ethylene mediates in the aluminium-induced inhibition of root elongation (Sun et al. 2010). Deficiency of other nutrients such as $\mathrm{P}$ and $\mathrm{Fe}$ induce morphological changes in root epidermal cells that are also mediated by ethylene (Schmidt \& Schikora 2001).
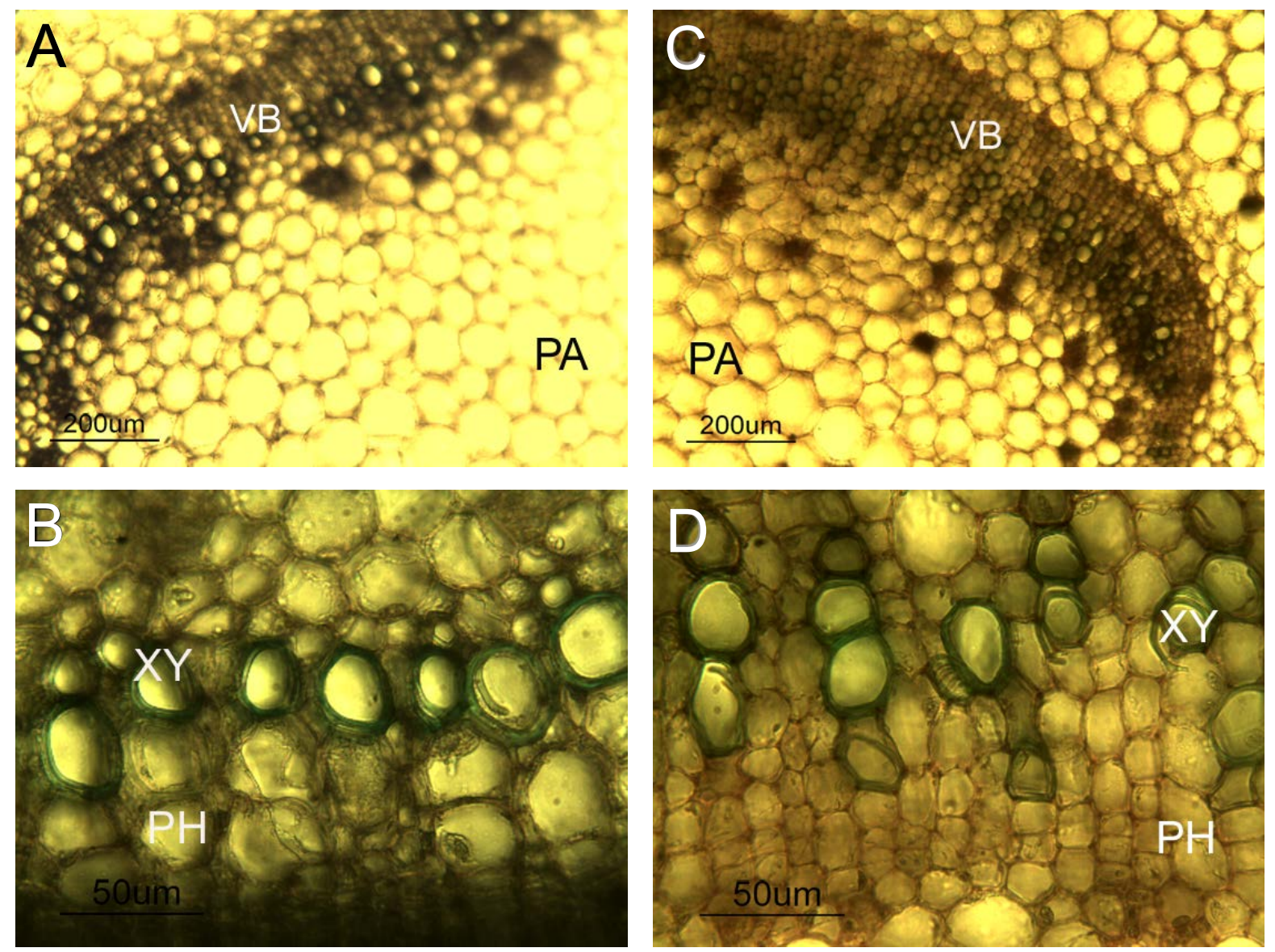

Figura 8. Sección transversal de tallo de tabaco de pota cultivado bajo condiciones adecuadas (A, B) y deficitarias (C, D) de boro. EP: epidermis; PA: parénquima; VB: haces vasculares; XY: xilema; PH: floema; $\mathrm{CH}$ : colénquima; VC: cambium vascular.

Figure 8. Cross sections of tobacco stem grown under adequate (A, B) or low (C, D) B supply. EP: epidermis; PA: parenchyma; VB: vascular bundles; XY: xylem; PH: phloem; $\mathrm{CH}$ : collenchyma; VC: vascular cambium. 


\section{References}

Blevins DG. \& Lukaszewski KM. 1998. Boron in plant structure and function. Annual Review of Plant Physiology and Plant Molecular Biology, 49: 481-500.

Broadley M, Brown P, Cakmak I, Rengel Z \& Zhao F. 2012. Function of nutrients: micronutrients. In Marschner's mineral nutrition of higher plants. (Marschner P. ed.). USA: Academic Press, pp. 191248.

Brown PH \& Hu H. 1997. Does boron play only a structural role in the growing tissues of higher plants? Plant and Soil 196: 211-215.

Brown PH, Bellaloui N, Wimmer MA, Bassil ES, Ruiz J, $\mathrm{Hu} \mathrm{H}$, Pfeffer H, Dannel F \& Römheld V. 2002. Boron in plant biology. Plant Biology 4: 205-223.

Cakmak I \& Romheld V. 1997. Boron deficiency-induced impairments of cellular functions in plant. Plant and Soil 193: 71-83.

Camacho-Cristóbal JJ \& González-Fontes A. 1999 Boron deficiency causes a drastic decrease in nitrate content and nitrate reductase activity, and in- creases the content of carbohydrates in leaves from tobacco plants. Planta 209: 528-536.

Camacho-Cristóbal JJ, Herrera-Rodríguez MB, Beato VM, Rexach J, Navarro-Gochicoa MT, Maldonado JM \& González-Fontes A. 2008. The expression of several cell wall-related genes in Arabidopsis roots is down regulated under boron deficiency. Environmental and Experimental Botany 63: 351-358.

Davies PJ. 1987. Plant hormones and their role in plant growth and development. Dordercht, The Netherlands: Kluwer Academic publishers.

de Oliveira RH, Milanez CRD, Moraes-Dallaqua MA \& Rosolem CA. 2006. Boron deficiency inhibits petiole and peduncle cell development and reduces growth of cotton. Journal of Plant Nutrition, 29: 2035-2048.

Dell B \& Huang L. 1997. Physiological response of plants to low boron. Plant and Soil 193: 103-120.

El-Shintinawy F. 1999. Structural and functional damage caused by boron deficiency in sunflower leaves. Photosynthetica 36: 565-573.

Findeklee P \& Goldbach HE. 1996. Rapid effects of boron deficiency on cell wall elasticity modulus in Cucurbita pepo roots. Botanica Acta 109: 463-465.
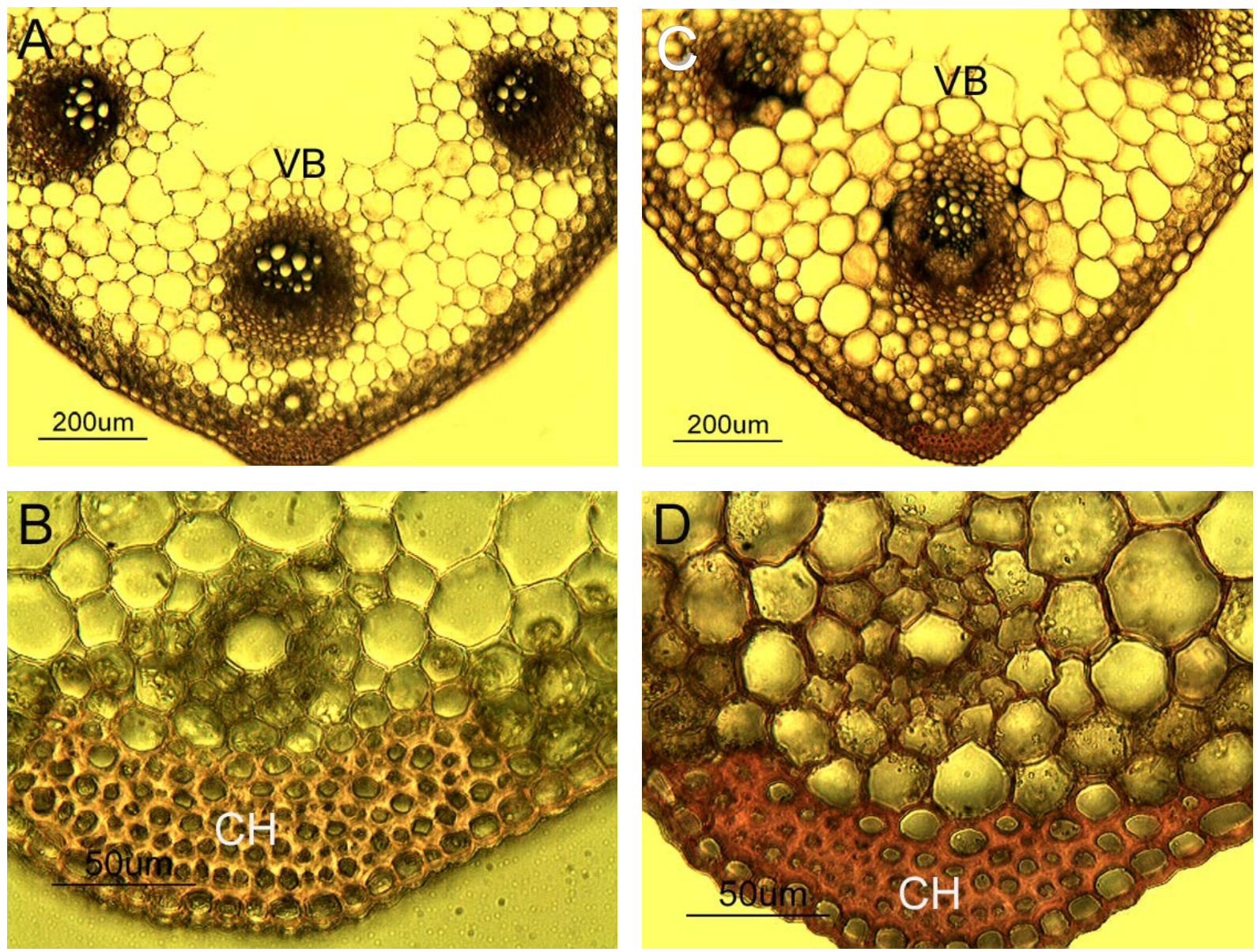

Figura 9. Sección transversal de tallo de apio cultivado bajo condiciones adecuadas (A, B) y deficitarias (C, D) de boro. EP: epidermis; PA: parénquima; VB: haces vasculares; XY: xilema; PH: floema; $\mathrm{CH}$ : colénquima; VC: cambium vascular.

Figure 9. Cross sections of celery stem grown under adequate (A, B) or low (C, D) B supply. EP: epidermis; PA: parenchyma; VB: vascular bundles; XY: xylem; PH: phloem; $\mathrm{CH}$ : collenchyma; VC: vascular cambium. 
Hajiboland R, Bastani S \& Bahrami-Rad S. 2011. Effect of light intensity on photosynthesis and antioxidant defense in boron deficient tea plants. Acta Biologica Szegediensis 55: 265-272.

Hajiboland R \& Farhanghi F. 2011. Effect of low boron supply in turnip plants under drought stress. Biologia Plantarum 55: 775-778.

Hajiboland R. \& Farhanghi F. 2010. Remobilization of boron, photosynthesis, phenolic metabolism and antioxidant defense capacity in boron-deficient turnip (Brassica rapa L.) plants. Soil Science Plant Nutrition 56: 427-437.

Hoagland DR \& Arnon T. 1950. The water culture method for growing plants without soil. Circular 347 . Berkeley, CA: California Agricultural Experiment Stations.

Hu H \& Brown PH. 1994. Localization of boron in cell walls of squash and tobacco and its association with pectin. Plant Physiology 105: 681-689.

Jensen WA. 1962. Botanical histochemistry. Principles and practice. San Francisco: Freeman Co.

Kouchi H \& Kumazawa K. 1976. Anatomical responses of root tips to boron deficiency: III. Effect of boron deficiency on sub-cellular structure of root tips, particularly on morphology of cell wall and its related organelles. Soil Science Plant Nutrition 22: 53-71.

Le J, Vandenbussche F, Van Der Straeten D \& Verbelen J-P. 2001. In the early response of Arabidopsis roots to ethylene, cell elongation is up- and down regulated and uncoupled from differentiation. Plant Physiology 125: 519-522.

Loomis WD \& Durst RW. 1992. Chemistry and biology of boron. Biofactors 3: 229-239.

Marschner H. 1995. Mineral nutrition of higher plants. 2nd Edition. London, UK: Academic Press.

Martín-Rejano EM, Camacho-Cristóbal JJ, HerreraRodríguez MB, Rexach J, Navarro-Gochicoa MT \& González-Fontes A. 2011. Auxin and ethylene are involved in the responses of root system architecture to low boron supply in Arabidopsis seedlings. Physiologia Plantarum 142: 170-178

Matoh H. 1997. Boron in plant cell walls. Plant and Soil 193: $59-70$

Matoh T \& Kobayashi M. 2002. Boron function in plant cell walls. Research progress since 1997. In Boron in plant and animal nutrition (Goldbach HE, Rerkasem B, Wimmer MA, Brown PH, Thellier M, Bell RW, eds.) New York: Academic Press, pp. 143-155.

Mengel K \& Kirkby E. 2005. Principles of plant nutrition. Dordercht, The Netherlands: Kluwer Academic Publishers.

O'Neill MA, Warrenfeltz D, Kates K, Pellerin P, Doco T,
Darvill AG \& Albersheim P. 1996. Rhamnogalacturonan-II, a pectic polysaccharide in walls of growing plant cell, forms a dimmer that is covalently crosslinked by a borate ester. Journal of Biological Chemistry 271: 22923-22930.

O'Neill MA, Eberhard S, Albersheim P \& Darvill AG. 2001. Requirement of borate cross-linking of cell wall rhamnogalacturonan II for Arabidopsis growth. Science 249: 846-849.

O'Neill MA, Ishii T, Albersheim P \& Darvill AG. 2004. Rhamnogalacturonan II: structure and function of a borate cross linked cell wall pectic polysaccharide. Annual Review of Plant Biology 55: 109-39.

Pérez-Torres CA, López-Bucio J, Cruz-Ramírez A, Ibarra-Laclette E, Dharmasiri S, Estelle M \& HerreraEstrella L. 2008. Phosphate availability alters lateral root development in Arabidopsis by modulating auxin sensitivity via a mechanism involving the TIR1 auxin receptor. Plant Cell 20: 3258-3272.

Robertson GA, \& Loughman BC. 1974. Response to boron deficiency: A comparison with responses produced by chemical methods of retarding root elongation. New Phytologists 73: 821-832.

Rosolem CA \& Costa A. 2000. Cotton growth and boron distribution in the plants as affected by a temporary deficiency of boron. Journal of Plant Nutrition 23: 815-825.

Rosolem CA \& and Leite VM. 2007. Coffee leaf and stem anatomy under boron deficiency. Revista Brasileira de Ciência do Solo 31:477-483.

Sanfuentes JR. 1966. Critical B concentration in cotton (Gossypium hirsutum L., cv. IAC 12). Master thesis, University of São Paulo, Brazil.

Schmidt W \& Schikora A. 2001. Different pathways are involved in phosphate and iron stress-induced alterations of root epidermal cell development. Plant Physiology 125: 2078-2084.

Stahl Y \& Simon R. 2010. Plant primary meristems: shared functions and regulatory mechanisms. Current Opinion in Plant Biology 13: 53-58.

Sun P, Tian Q-Y, Chen J \& Zhang WH. 2010. Aluminiuminduced inhibition of root elongation in Arabidopsis is mediated by ethylene and auxin. Journal of Experimental Botany 61: 347-356.

Wolf S, Hématy K \& Höfte H. 2012. Growth control and cell wall signaling in plants. Annual Review of Plant Biology 63: 381-407.

Shorrocks VM. 1997. The occurrence and correction of boron deficiency. Plant and Soil 193: 121-148.

Ye ZH. 2002. Vascular tissue differentiation and pattern formation in plants. Annual Review of Plant Biology 53: 183-202. 

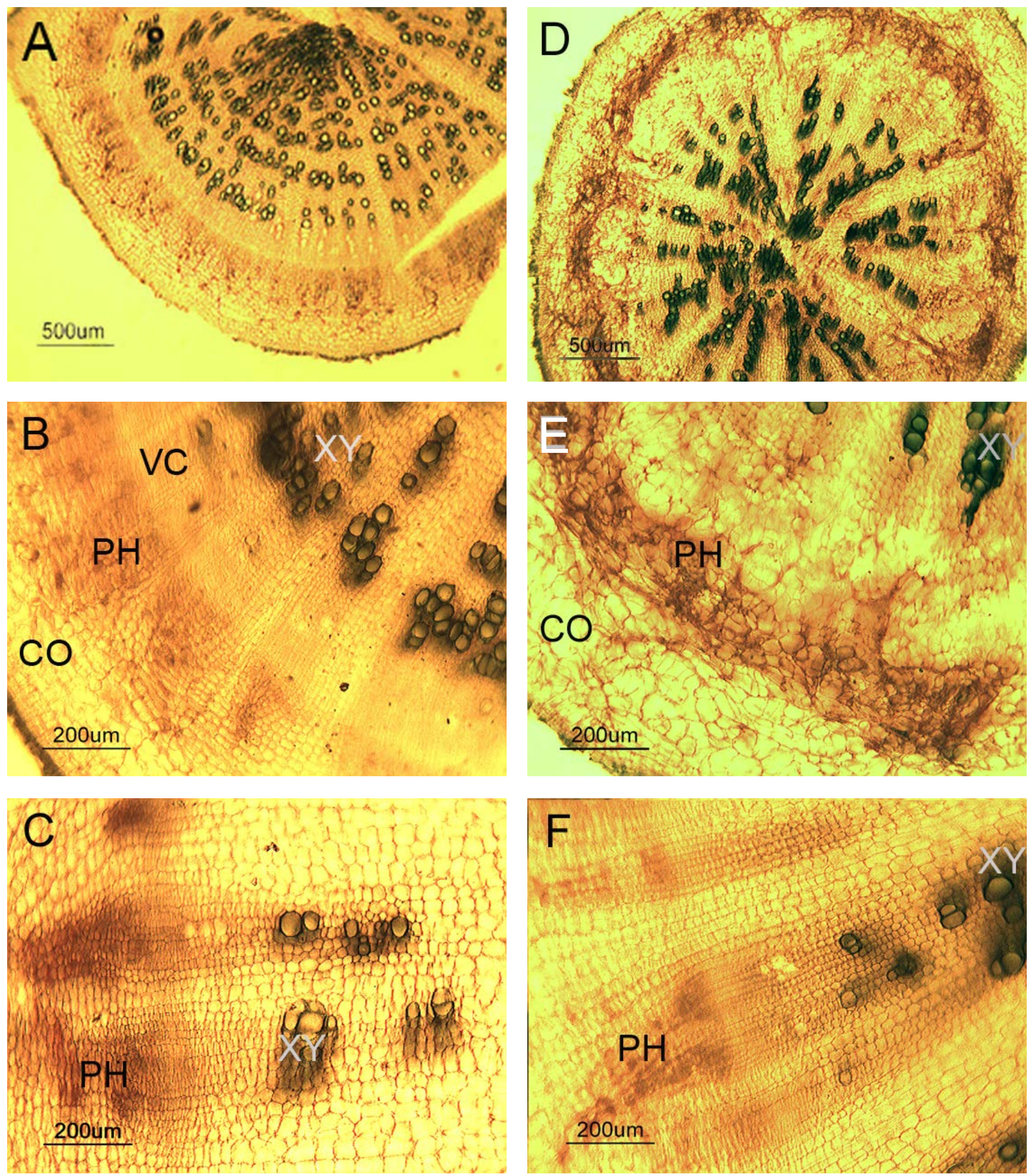

Figura 10. Sección transversal de raíz (A, B, D, E) y raíz tuberosa (C, F) de nabo cultivado bajo condiciones adecuadas (A, B) y deficitarias (C, D) de boro. EP: epidermis; PA: parénquima; VB: haces vasculares; XY: xilema; PH: floema; CH: colénquima; VC: cambium vascular; CO: córtex.

Figure 10. Cross sections of turnip root (A, B, D, E) and storage root (C, F) under adequate (A, B, C) or low (D, E, F) B supply. EP: epidermis; PA: parenchyma; VB: vascular bundles; XY: xylem; PH: phloem; $\mathrm{CH}$ : collenchyma; VC: vascular cambium; CO: cortex. 